\title{
Pectin: Properties and utilization in meat products
}

\author{
EInaz SHAREFIABADI ${ }^{\circledR}$, Meltem SERDAROĞLU® $^{\circledR}$
}

Cite this article as:

Sharefiabadi, E., Serdaroğlu, M. (2021). Pectin: Properties and utilization im meat products. Food and Health, 7(1), 64-74.

https://doi.org/10.3153/FH21008

Ege University, Engineering Faculty, Food Engineering Department, 35100 Bornova, İzmir, Turkey

ORCID IDs of the authors: E.S. 0000-0002-4382-0469 M.S. 0000-0003-1589-971X

Submitted: 18.09 .2020

Revision requested: 16.10 .2020

Last revision received: 21.10 .2020

Accepted: 22.10 .2020

Published online: 11.12 .2021

Correspondence: Meltem SERDAROĞLU

E-mail: meltem.serdaroglu@ege.edu.tr

\begin{abstract}
In recent years, there is increased awareness of conscious consumers about the fact that foods they eat are related directly to their health. In meat industry research and development, studies have accelerated to formulate healthier meat products formulations using plant sources as additive which are also expected to improve the functional properties of the product. Pectin is a water soluble fiber with a structural complexity that occurs naturally in the cell walls of fruits and vegetables, contributes to reducing the risk of cancer, and has some health benefits. Gelation is the most unique property of pectin; it forms a gel in the presence of $\mathrm{Ca}^{2+}$ ions or sugar and acid. Pectin presents good water and fat binding property. Therefore, it can be used as a gelling agent, film/coating, and emulsifier and in low-calorie meat products as fat and /or sugar substitution (dietary fiber), as a natural component contributes to phosphate substitution and medical delivery systems in meat products. In this paper, it was aimed to discuss the physico-chemical properties, health implications of pectin and its potential applications in meat products.
\end{abstract}

Keywords: Pectin, Meat products, Gelling agent, Restructured meat, Low-fat products

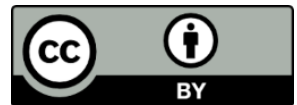

(C) 2021 The Author(s)

Available online at

http://jfhs.scientificwebjournals.com 


\section{Introduction}

Pectin is a type of structural fiber found in the primary cell wall and intracellular layer of plant cells mainly in fruits, such as apples, oranges, lemons, and so on (Mudgil, 2017).

Pectin contains a polysaccharide backbone with an a-(1-->4)linked D-galacturonic acid. The acid groups along the chain are largely esterified with methoxy groups in the natural product. There can also be acetyl groups present on the free hydroxy groups. As shown in Figure 1, esterification is the reaction between carboxylic acid and alcohol or compounds containing the hydroxyl group (usually methanol) to form ester and water (Parkinson, 2014).<smiles>[R]C(=O)O</smiles>

carboxylic acid

$$
+\quad \mathrm{R}^{\prime} \mathrm{OH}
$$
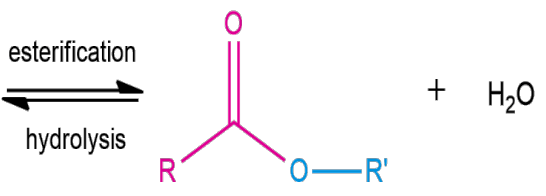

alcohol ester
Figure 1. Esterification mechanism of pectin (Parkinson, 2014).
Degree of methyl esterification ranges between $0-100 \%$ and on the basis of esterification, there are two different types of peçtin; high methoxy (HMP) and low methoxy pectin (LMP) (Ramirez-Suarez et al., 2017).

Table 1 shows pectin content of various plants. Apple pomace and citrus fruit peels are commercially acceptable sources of pectin (Thakur et al., 1997). However, it has been extracted from different plants such as sunflower head, mango peel, soybean hull, sugar beet pulp, chickpea husk, etc. ( Fajardo et al.,2016). Pectin from apple forms a more elastic-viscous gel however, citrus pectin displays a more elastic-brittle gel (Masuelli, 2019).

Utilization of pectin has been allowed in all countries, FAO/WHO committee recommended acceptable daily intake of pectin has no limitation and it is as a safe additive except where specified by good manufacturing practice. Pectin is used as a thickening agent, gelling agent, texturizer, emulsifier, stabilizer, and fat or sugar replacer in food industry, the major application of pectin is based on its gelling properties (Thakur et al., 1997). The source and the method of extraction have an influence on the structure and properties of pectin such as viscosity and gelling ability and thus their application in food industry (Gawkowska et al., 2018).

In the present review, it was aimed to investigate the functional properties of pectin and its usages in meat product formulations.

Table 2. Pectin content of various plants

\begin{tabular}{|c|c|c|}
\hline Plants & Pectin & Reference \\
\hline Sugar beet and sunflower head & $10-20 \%$ & Yancheva et al., 2016 \\
\hline Cocoa husks & about $9 \%$ & Yancheva et al., 2016 \\
\hline Beet and potato pulp and Soy hull & $26-28 \%$ & Yancheva et al., 2016 \\
\hline Apple pomace & $10-17 \%$ & Sharma et al., 2014; Fajardo et al., 2016 \\
\hline Citrus peels & $20-30 \%$ & Panchami \& Gunasekaran, 2017; Fajardo et al., 2016 \\
\hline Plants of Lupinus genus & $1.5 \%-7 \%$ & Valdés et al., 2015 \\
\hline Burdock from the Arctium genus & Higher than $21 \%$ & Valdés et al., 2015 \\
\hline Peach & up to $10 \%$ & Valdés et al., 2015 \\
\hline Orange peel/ pomace and seed & $30-50 \%$ & Begum et al., 2017 \\
\hline Pineapple & $54 \%$ & Begum et al., 2017 \\
\hline
\end{tabular}




\section{Pectin Extraction Methods}

According to the previous studies, some parameters mainly $\mathrm{pH}$, time and temperature influence pectin extraction (Yapo et al., 2007; Fathi et al., 2012). Pectin can be extracted by various methods from the cell-wall material in laboratoryscale such as cold/hot water or buffer solutions, cold diluted sodium hydroxide, cold/hot solutions of chelating agents and hot diluted acids (Levigne et al., 2002). Figure 2 shows an optimized method of pectin extraction. Pectin can have physical harm in structure when extracted fully by acidic extraction and acid extraction of pectin has no environmental safety. Therefore, the combination of acid extraction and other methods is used. In recent years, searching for alternative methods that have fewer disadvantages is continued such as using microbial enzymes or enzyme complexes and ultrasound-assisted, ohmic- assisted, microwave-assisted, etc. extractions (Ptichkina et al., 2008; Gavahian et al., 2019). As an example, sonication of pectin leads to increased antioxidant capacity, $200 \mathrm{~W}$ and $400 \mathrm{~W}$ sonicated pectin have higher oxygen radical absorbance capacity and FRAP values than native pectin. Therefore, ultrasound offers an effective and green process for pectin transformation and creation of antioxidant potent pectin products (Ogutu and $\mathrm{Mu}, 2017$ ).

\section{Characteristics of Pectin}

\section{Solubility and Dispersibility}

There are two types of pectin depending on the solubility: water-soluble and water-insoluble pectin. This property is determined by the number and distribution of methoxy groups and the degree of polymerization. It means that a decrease in molecular weight and an increase the (degree of esterification) DE cause to increase solubility increases. Other parameters that have an impact on solubility are $\mathrm{pH}$, temperature, and the nature and concentration of the solute present (Axelos and Thibault, 1991).

Dispersibility means the ease of solubilization of pectin, which is more important than solubility. When dry powdered of pectin added to water, attends to hydrate rapidly and forming clumps (Kachare et al., 2020). Formation of the clump can be prevented by using water-soluble carrier material with dry powdered pectin or improving the dispersibility of pectin by mixing (5/10 parts by weight) fine-powdered sugar or $D$ glucose (the common dispersing agents) and pectin (Axelos and Thibault, 1991).

\section{Gelation}

Gelation is the most unique property of peçtin, pectin forms gels in the presence of $\mathrm{Ca}^{2+}$ ions or sugar and acid also traps the liquid by forming a three-dimensional network due to the merging or cross-linking of long polymer chains (Narasimman and Sethuraman, 2016). Two different pectin types form gels under completely different conditions. The ester group is less hydrophilic than the carboxyl group; therefore, HMP makes gel at a higher temperature than the LMP. Low methoxy pectin forms gel in $\mathrm{pH}(2-6)$ and presence of divalent ions such as calcium, high methoxy pectin forms a gel in the presence of sugar ( $>50 \%)$ and acid $(\mathrm{pH}: 3.1-3.6)$ (Narasimman and Sethuraman, 2016).

Pectin source plant

Blanching (boiling at $95^{\circ} \mathrm{C}$ for 5 minutes)

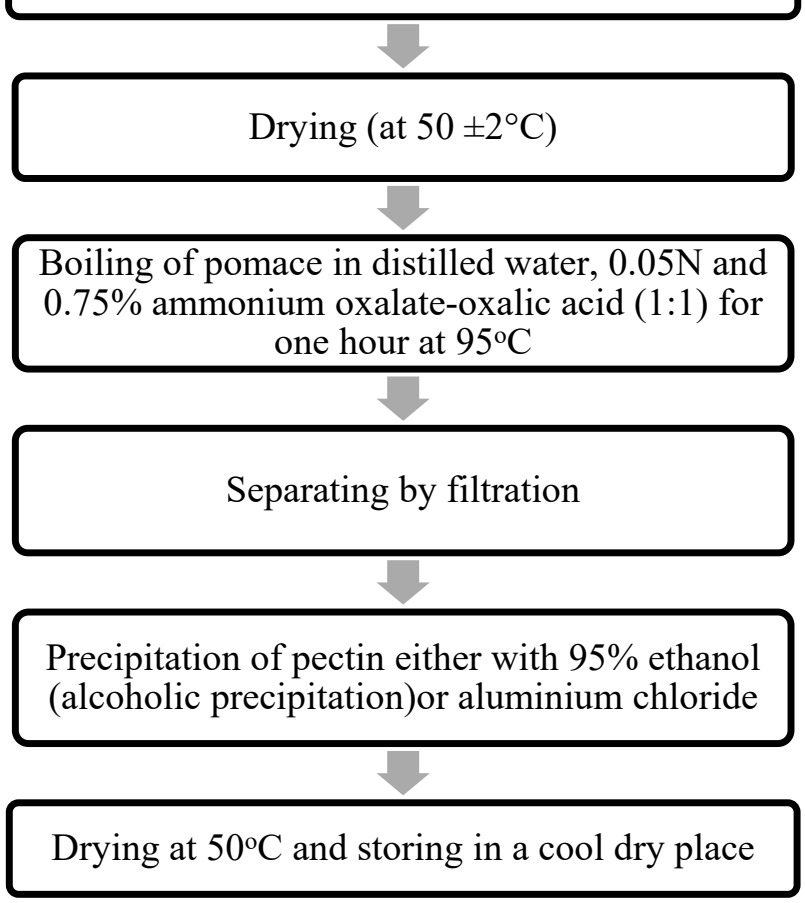

Figure 3. An optimized method for pectin extraction (Sharma et al., 2014) 
Table 3. The yield of pectin extraction methods (Vales et al., 2015)

\begin{tabular}{ccc}
\hline Sources & Methods & Yield \\
\hline Sugar beet pulp & Citric acid, $99^{\circ} \mathrm{C}$ & 23.95 \\
\hline $\begin{array}{c}\text { Watermelon } \\
\text { seed }\end{array}$ & $\mathrm{HCl}, 85^{\circ} \mathrm{C}$ & 19.75 \\
\hline \begin{tabular}{c} 
Tomato peel \\
\multicolumn{3}{c}{ Oxalic acid and ammonium ox- } \\
alate, $90^{\circ} \mathrm{C}$
\end{tabular} & 32.0 \\
& (two steps 24 and $12 \mathrm{~h}$ ) & \\
\hline Mango peel & Sulfuric acid in the water, $90^{\circ} \mathrm{C}$ & $>70$ \\
\hline Sunflower head & Sodium citrate, $85^{\circ} \mathrm{C}$ & 16.90 \\
\hline
\end{tabular}

\section{Pectin as Emulsifier}

Emulsions assist encapsulation of the bioactive compounds. Depending on the disperse phase, there are two types of liquid emulsion: oil droplet in water $(\mathrm{O} / \mathrm{W})$ and water droplet in oil $(\mathrm{W} / \mathrm{O})$. Meat emulsion is an example of $\mathrm{O} / \mathrm{W}$ emulsion, margarine and butter, by contrast are examples of W/O emulsion (Fajardo et al., 2016). A multiple (double) emulsion system defined as 'emulsion in emulsion', in which oil-in-water $(\mathrm{O} / \mathrm{W})$ and water-in-oil $(\mathrm{W} / \mathrm{O})$ are together. For example in $\mathrm{W} 1 / \mathrm{O} / \mathrm{W} 2$ double emulsion, $\mathrm{W} 1$ and $\mathrm{W} 2$ are internal and external water phases respectively, there are two different interface layers W1-O (internal water droplets are surrounded by oil) and O-W2 (oil droplets are surrounded by water (Öztürk et al., 2016).

Emulsifiers are used to mix two liquids that are normally immiscible for manufacturing desirable products. Emulsifiers divided into small-molecular surfactants (lecithin, etc.) and macro-molecular emulsifiers (proteins and plant-based polymers such as soy polysaccharide, pectin, etc.). Good emulsifiers should have low molecular weight, rapidly reduce the interfacial tension and soluble in the external phase. Pectin has been reported to exhibit surface-active property in oil-water interface and thereby stabilizing the oil droplets in emulsion systems (Funami et al., 2007)

$\mathrm{O} / \mathrm{W}$ emulsion is stabilized by steric and electrostatic interaction of pectin. Pectin improves the stability of emulsion, with the addition of pectin viscosity of the emulsion increased, therefore movement of oil droplets are limited. Molecular weight effects emulsifying capacity of pectin. Small emulsion droplets are efficiently stabilized by low molecular weight pectin. Researches also indicated that pectin increases colloidal binding and coagulation of soluble proteins. The high molecular weight of pectin is an important factor that prevents protein coagulation. Many factors may influence the interactions, such as $\mathrm{DE}$ of pectin, $\mathrm{pH}$ and processing conditions.
Pectins can stabilize the protein in acidic media through conjugation or complexation. The rate of structure development in pectin gels depends on temperature, pectin concentration and hydration of pectin. (Axelos and Thibault, 1991; Yapo et al., 2007; Fajardo et al., 2016)

Pectin-protein molecules form a network that surrounded oil droplets in emulsion based food products. Nowadays, pectin is used in emulsified low-fat meat products, dairy products, etc. (Masuelli, 2019).

\section{Usage of Pectin in Meat Products}

Depending on the functional properties such as gelling ability, water binding ability and acting as an emulsifier pectin is one of the natural ingredients for healthy meat products formulations. Pectin is widely used in meat products to form a gel and/or as a thickener. This property is related to the size, shape, chain length and total negative charge in galacturonic acid structure of pectin molecule.

The interactions between pectin and meat proteins showed in Figure 3, 4 and 5. Actin interacts with pectin through eighteen amino acids; there are eight $\mathrm{H}$-bonds that play an important role in the correct positioning of pectin into the actin surface (Figure 3). Myosin interacts with pectin through thirteen amino acid and twelve $\mathrm{H}$-bonds play an important role in the correct positioning of pectin into the myosin surface (Figure 4). Collagen interacts with pectin through thirteen amino acid and a total of six H-bonds play an important role in the correct positioning of pectin into the collagen surface (Figure 5).

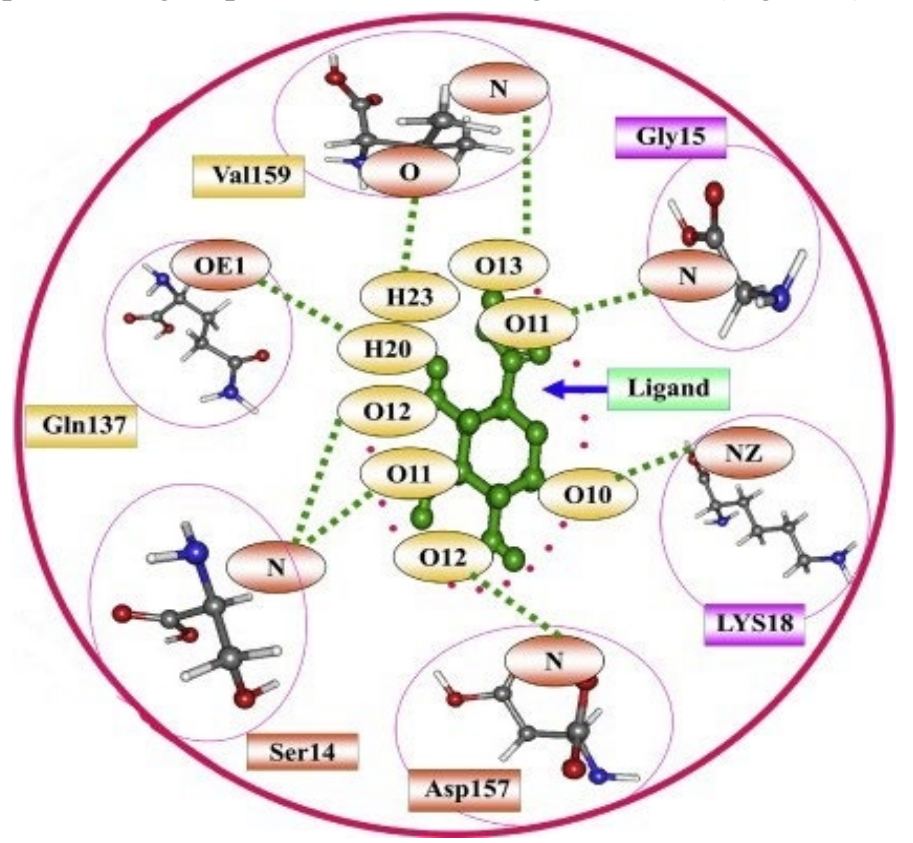

Figure 3. Complex structure pectin + actin (Ahmad et al., 2020) 


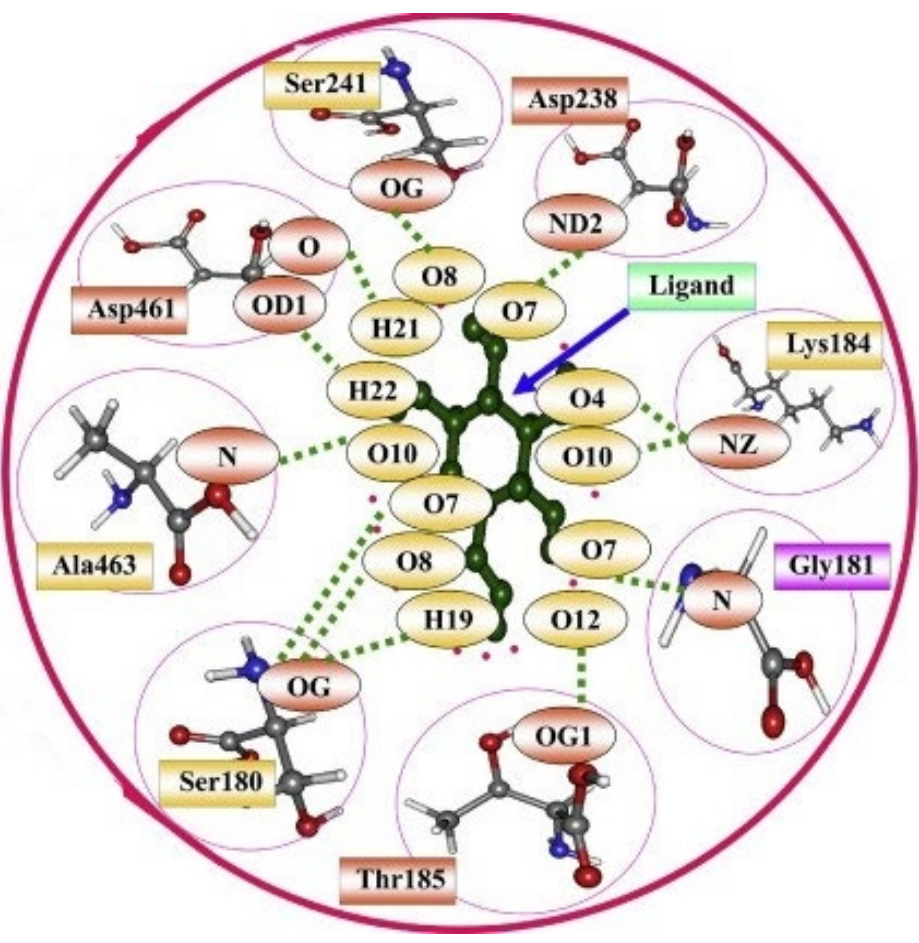

Figure 4. Complex structure pectin + myosin (Ahmad et al., 2020)

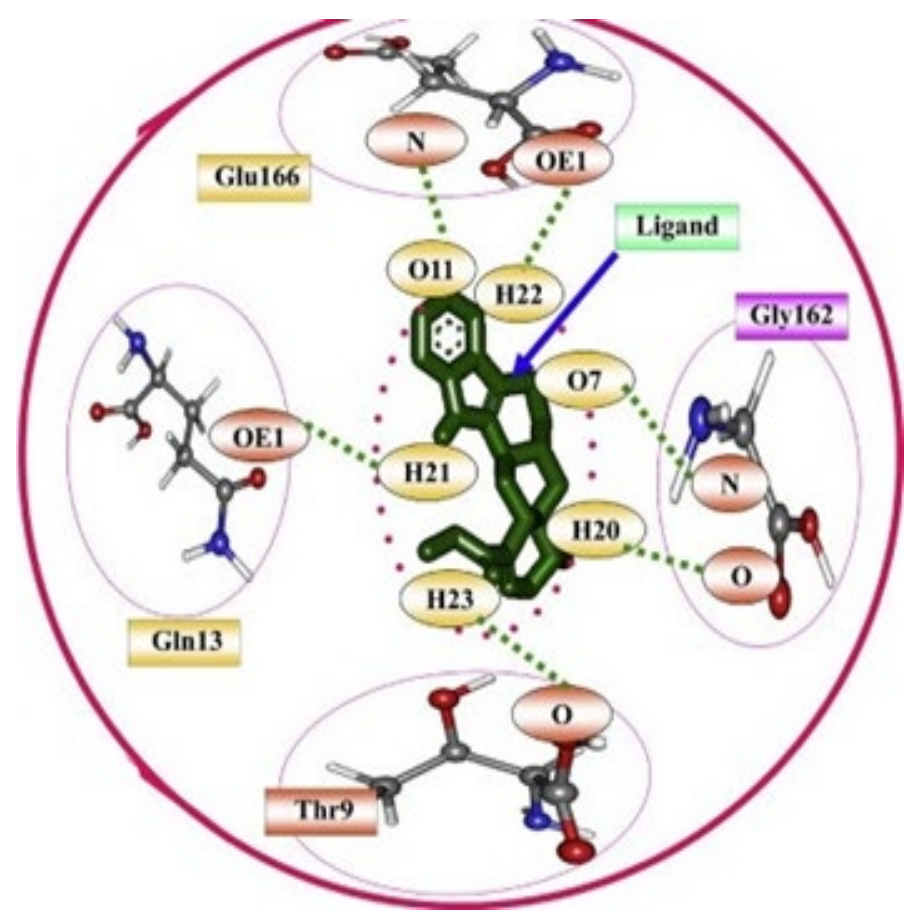

Figure 5. Complex structure pectin + collagen (Ahmad et al., 2020)
Myofibrillar proteins represent the functional part of meat proteins, they are extracted from the muscle tissue, followed by the accumulation around oil droplets and/or participation in the formation of a three-dimensional network gel during meat processing, ultimately contributing to improved emulsion stability, water-holding capacity (WHC), and texture of meat products. The examination of zeta potential and hydrodynamic size has demonstrated that histidine inhibits the aggregation of myosin and increases the solubility of myosin. Recently, it was highlighted that both lysine and arginine improve the water holding capacity and texture. The myosin molecule has an asymmetric structure with two globular heads and a rod-like tail. It associates with insoluble fibers through electrostatic tail-to-tail interaction under physiological conditions. Consequently, pectin has a good interaction with meat proteins based on the H-bond formation and free binding energy (Ahmad et al., 2020).

\section{Film/Coating}

Films or coatings are defined as a layer on the food surface or placed between food components (Korkmaz, 2018). Their function is to extend the shelf life of the products and provide a barrier against various hazards. Films should provide mechanical properties and restrict the migration of gas in food wrapping and/or coating. Edible films can represent physical protection, reduction of moisture and lipid transition, limit absorption of oxygen, improve handling features and can be contacted directly with food. Some natural components such as carbohydrates and proteins are used for the manufacturing of films, which have nutritional value, biodegradability, and environmental compatibility (Maftoonazad et al., 2007). Pectin and its derivatives are used in many biodegradable packaging materials that serve as moisture, oil, and aroma barrier, reduce respiration rate and oxidation of food (Ciolacu et al., 2014). Pectin-based edible films and coatings, either alone or enriched with antimicrobial and antioxidant substances, were investigated in meat and meat products (Tural et al., 2017).

Edible films are developed to be used as carrier for additive with specific functions such as anti-browning, antimicrobial agents, texture enhancers, nutrients, probiotics, and flavors (Falguera et al., 2011). As an additional barrier against pathogenic and spoilage microorganisms, antimicrobials are incorporated into edible films to inhibit food surface contamination. Ravishankar et al., (2012) are investigated the incorporation of carvacrol and cinnamaldehyde as antimicrobials into films against Listeria monocytogenes on contaminated ham and bologna. The effectivity of pectin films on ham was more than bologna (Ravishankar et al., 2012). Borges et al., (2016) evaluated the effect of free nisin and nisin-loaded pec- 
tin nanoparticles on the growth rate of Listeria innocua in fermented pork meat model at different temperatures and fermentation conditions during 96 hours. Using both nisin and nisin-loaded pectin nanoparticles had significant inhibition effect on Listeria innocua (Borges et al., 2016).

Casings prepared with pectin or combination of gelatin/sodium alginate have been used for sausage production. Sensory analysis of sausages indicated that pectin casings were more preferred to gelatin/sodium alginate casings for sausages (Liu et al., 2007). Kang et al., (2007) studied the physicochemical, microbiological and sensory quality of irradiated cooked pork patties coated with pectin containing green tea leaf extract, found that lipid oxidation and microbial growth decreased in coated samples.

\section{Pectin as Fat Substitution}

Fat has an important role in meat products, including stabilizing meat emulsions, increasing cooking yield and water holding capacity, and improving texture. Fat also has an impact on binding, rheological and structural properties of meat products. However, high-fat diets are related to obesity, high blood pressure, cardiovascular and coronary heart diseases (Choi et al., 2016). Three different techniques can be applied to reduce the fat content in meat product formulations; changing the chemical composition of the carcass, using meat with low-fat content (manipulating animal raw materials or selecting lean meat) and using fat substitutes. Different fat substitutes have been used to ensure the functionality of fat. Substitutes derived from carbohydrates are generally hydrophilic because they have large number of hydrogen bonds with water, which forms an emulsion system on the targeted food tissue (Schmiele et al., 2015; Tufeanu and Tita, 2016).

Using pectin can be considered a feasible way to replace or reduce animal fat in meat products. Méndez-Zamora et al. (2015) studied the effect of substitution of animal fat with different formulations of pectin and inulin on chemical composition, textural, and sensory properties of emulsion type sausages and they recorded combined using of $15 \%$ pectin and $15 \%$ inulin could be used as animal fat replacer.

Effects of carrageenan and/or pectin gel (20\%) were evaluated in low-fat beef frankfurters, frankfurters formulated with either carrageenan or carrageenan/ pectin gel had acceptable sensory scores (Candogan and Kolsarıc1, 2003). In another study, different fat replacers were investigated in low-fat frankfurters. According to the results, the emulsion stability of the batter was affected in different way due to the addition of different hydrocolloids. Samples including 1\% pectin concentration had the highest cooking yield and water holding capacity (WHC) similar to control. TBA values decreased by addition of $0.5 \%$ pectin. Sensory analysis showed that one of the closest samples to the control were $0.5 \%$ pectin by the consumers (Jafarzadeh Yadegari, 2015). Han and Bertram (2017) evaluated using pectin in fat-reduced pork meat model system; pectin added samples showed similar properties with the normal fat controls.

Replacing pork back fat with $35 \%$ olive oil resulted positive scores in sensory characteristics when $0.45 \%$ of pectin was added (Pappa et al., 2000).

The substitution of 5\% mango peel pectin to fat content in Chinese sausage enhanced color and conserve the physical qualities as well as sensory attribute

Plant sources containing pectin were also used in meat industry. Apple pomace was used in different meat products such as chicken sausages (Yadav et al., 2016), buffalo meat sausage (Younis and Ahmad, 2015) and reduced-fat chicken sausages (Choi et al., 2016). All these studies showed an increment in cooking yield, WHC, emulsion stability. Çoksever (2009) investigated the effects of bitter orange albedo at different concentrations on the quality of naturally fermented Turkish style sausages and results were similar to pectin uses studies. Decreasing in weight loss and increasing in cooking yield were observed by the addition of $1 \%$ soy hull pectin in both fresh and frozen/thawed beef patties while TBARS value, statistically not affected and sensory scores were similar to control (Kim et al. 2016).

\section{Pectin Assisted Phosphate-Free Meat Products}

Phosphates are multi-functional and low-cost compounds. Phosphates enhance product yield by increasing water holding capacity, flavor, and texture as well as having antioxidant functions as a metal chelating agent. However, researches show that high phosphate intake has several health risks. Therefore, there is a trend for reducing the amount of use in formulations or replacing them with natural components that meet their effects (Tabak et al., 2019). In phosphate free meat products, natural calcium powders are widely used as alkaline ingredients to increase the $\mathrm{pH}$ value of products. Since low methoxy pectins form gels through calcium ions, low methoxy pectin is a promising additive for phosphate free meat product formulations. Besides this due to its water-binding property pectin can assist or enhance water-binding properties of phosphate reduced and phosphate free meat products (Ko et al., 2014; Cho et al. 2017; Cho et al. 2018).

Tabak et al., (2019) showed combined using of eggshell powder with pectin or carrageenan enhanced the technological and sensory qualities of phosphate free chicken patties. 


\section{Using Pectin in Restructured Meat Products}

Pectin specially amidated low methoxy pectin (ALMP) have certain functionality in gel products. ALMP is an anionic carbohydrate that its anionic groups interact with the cationic groups of protein and hydrogen bonds consequently, increase the functional and mechanical properties of protein systems. Therefore, its addition can affect the gelling process, depending on concentration and raw matter (Ramirez-Suarez et al., 2017). Gel matrix is formed by binding small pieces of meat as a result of solubilizing myofibrillar proteins in restructured meat products. Addition of pectin can improve one or more properties of solid food (patties) such as cohesion, firmness, juiciness, freeze/thaw stability or texture resistance to shrinking during cooking (Deo et al., 2019). Urestia et al., (2003) used different concentrations of ALMP for producing restructured fish to improve the quality properties of surimi. Results observed that $5 \%$ of ALMP decreased expressible water content in restructured products. $1 \%$ concentration of ALMP recommended to improved texture and gel strength in restructured fish (Urestia et al., 2003). Ramirez-Suarez et al., (2017) evaluated the effects of different concentration ALMP pectin on quality properties of jumbo squid (Dosidicus gigas) muscle gels due to the low functionality of muscle proteins and limited use. Texture was improved by adding ALMP. The highest WHC was shown in samples contain 3\% ALMP compared to control (Ramirez-Suarez et al., 2017). As shown in Table 3 besides other properties, pectin has potential as a preservative, carrier of materials, and provides good rheological properties.

\section{Health Benefits of Pectin}

Pectin presents cholesterol-lowering, serum glucose-lowering and anti-cancer activities due to the specific structural domains, carrying bioactive properties. Pectin as soluble fiber decreases blood serum total cholesterol and low-density lipoprotein cholesterol, without having any effect on high-density lipoprotein cholesterol. Pectin has a good potential in food delivery, pectic-oligosaccharides obtained in a refined form from apple pomace presented prebiotic effects, which contribute to a healthy environment (Naqash et al., 2017). Pectin reduces blood sugar when consumed with food and studies have shown that pectin reduces the risk of some cancer types. For example, studies showed that extraction of pectin from citrus fruits prevents the formation of spontaneous prostate cancer cells in the body. These studies have also demonstrated the relationship between pectin and decreasing the risk of prostate cancer (Çoksever, 2009).

Table 3. Review of recent researches

\begin{tabular}{llll}
\hline Products & Applications & Results & References \\
\hline $\begin{array}{l}\text { Beef, chicken filet, } \\
\text { (fish) }\end{array}$ & $\begin{array}{l}\text { Edible film containing pectin } \\
\text { for freshness }\end{array}$ & $\begin{array}{l}\text { High sensitivity to gaseous } \\
\text { amines and good standard } \\
\text { degradation markers }\end{array}$ & Dudnyk et al., 2018 \\
\hline Raw-fermented sausage & Incorporation of 3\% pectin & $\begin{array}{l}\text { Similar rheological properties as } \\
\text { the full-fat control }\end{array}$ & Zeeb et al., 2018 \\
\hline Emulsion-type sausage & $\begin{array}{l}\text { Incorporation of 1.88\% } \\
\text { pectin }\end{array}$ & Higher in softening value & Zeeb et al., 2018 \\
\hline Meat batter & $\begin{array}{l}15 \% \text { inulin and 15\% pectin } \\
\text { as a fat replacer }\end{array}$ & No effects on physical properties & Silva-Vazquez et al., 2018 \\
\hline Raw beef meat & $\begin{array}{l}\text { Edible pectin-fish gelatin } \\
\text { films }\end{array}$ & $\begin{array}{l}\text { Improving oxygen barrier and } \\
\text { delaying the lipid oxidation }\end{array}$ & Bermúdez-Oria et al., 2019 \\
\hline Meat sausage & $\begin{array}{l}\text { LM pectin(4\%)-encapsulated- } \\
\text { fat }\end{array}$ & $\begin{array}{l}\text { Preventing fat digestion and ab- } \\
\text { sorption/ improving texture }\end{array}$ & Santiaguín-Padilla et al.,2019 \\
\hline $\begin{array}{l}\text { Hamburger patty } \\
\text { (semi-finished products) }\end{array}$ & $\begin{array}{l}\text { Alginate-pectin with whey } \\
\text { protein concentrate }\end{array}$ & $\begin{array}{l}\text { Inhibiting lipid oxidation, } \\
\text { proving tenderness and better } \\
\text { quality }\end{array}$ & Barybina et al., 2019 \\
\hline Fresh pork loin & $\begin{array}{l}\text { Nanoemulsion loaded pectin } \\
\text { edible coating }\end{array}$ & $\begin{array}{l}\text { The best preservation and stability } \\
\text { in 15 days 4 }{ }^{\circ} \mathrm{C}\end{array}$ & Xiong et al.,2020 \\
\hline
\end{tabular}




\section{Conclusion}

Pectin is a water-soluble fiber and used in food industry as emulsifier, stabilizer, gelling, and thickening agent. Pectin presents in the cell walls of most plants, apple pomace and citrus peel are the two major sources of commercial pectin. Pectin extraction is a multiple-stage process in which hydrolysis and extraction of the pectin macromolecules from plant tissue and their solubilization takes place under the influence of different factors. Pectin has been used successfully for many years in food industry as a thickening, gelling agent and a stabilizer. Consumers have preferred products with natural additives while having the sensory properties of traditional food. Pectin is one of the promising natural additives for low fat meat products and also can be used in phosphate free formulations and emulsion type products due to the gelling and water binding ability. Pectin edible films incorporated with natural antimicrobials have potential application in preservation as active packaging materials for meat products.

\section{Compliance with Ethical Standard}

Conflict of interests: The authors declare that for this article they have no actual, potential or perceived the conflict of interests.

Ethics committee approval: The authors declare that this study does not require ethical permission.

Funding disclosure: -

Acknowledgments: -

Disclosure: -

\section{References}

Ahmad, S. S., Khalid, M., Younis, K. (2020). Interaction study of dietary fibers (pectin and cellulose) with meat proteins using bioinformatics analysis: An In-Silico study. LWTFood Science and Technology, 119, 108889.

https://doi.org/10.1016/j.lwt.2019.108889

Axelos, M. A., Thibault, J.-F. (1991). The chemistry of lowmethoxyl pectin gelation. In R. H. Walter (Ed.), The chemistry and technology of pectin (pp. 109-118). Academic Press. ISBN: 9780127338705

https://doi.org/10.1016/B978-0-08-092644-5.50011-X

Barybina, L.I., Oboturova, N.P., Datsko, V.A., Nagdalian, A.A., Kopchekchi, M.E., Ozheredova, N.A., Simonov, A.N. (2019). Hamburger patty development with alginatepectin meat emulsion. Journal of Hygienic Engineering and Design, 29, 111-118.
Begum, R., Aziz, M.G., Yusof, Y., Burhan, M. (2017). Extraction and characterization of pectin from jackfruit (Artocarpus heterophyllus Lam) waste. Journal of Pharmacy and Biological Science, 12(6), 42-49.

Bermúdez-Oria, A., Rodríguez-Gutiérrez, G., RubioSenent, F., Fernández-Prior, Á., Fernández-Bolaños, J. (2019). Effect of edible pectin-fish gelatin films containing the olive antioxidants hydroxytyrosol and 3, 4 dihydroxyphenylglycol on beef meat during refrigerated storage. Meat science, 148, 213-218.

https://doi.org/10.1016/j.meatsci.2018.07.003

Borges, A., Krivorotova, T., Barreto A.S., Fraqueza, M.J. (2016). Effect of nisin-loaded pectin nanoparticles on the survival of Listeria innocua in a meat model. In 62nd International Congress of Meat Science and Technology, Bangkok, Thailand.

Candogan, K., Kolsarici, N. (2003). The effects of carrageenan and pectin on some quality characteristics of low-fat beef frankfurters. Meat Science, 64, 199-206.

https://doi.org/10.1016/S0309-740(02)00181-X

Cho, M.G., Bae, S.M., Jeong, J.Y. (2017). "Eggshell and oyster shell powder as alternatives for synthetic phosphate: Effects on the quality of cooked ground pork products", Korean Journal for Food Science of Animal Resources, 37(4), 571.

https://doi.org/10.5851/kosfa.2017.37.4.571

Cho, M.G., Jeong, J.Y. (2018). Effects of Calcium Powder Mixtures and Binding Ingredients as Substitutes for Synthetic Phosphate on the Quality Properties of Ground Pork Products. Korean Journal for Food Science of Animal Resources, 38(6), 1179-1188.

https://doi.org/10.5851/kosfa.2018.e49

Choi, Y.S., Kim, Y.B., Hwang, K.E., Song, D. H., Ham, Y.K., Kim, H.W., Sung, J.M., Kim, C.J. (2016). Effect of apple pomace fiber and pork fat levels on quality characteristics of uncured, reduced-fat chicken sausages. Poultry Science, 95(6), 1465-1471.

https://doi.org/10.3382/ps/pew096

Ciolacu, L., Nicolau, A.I., Hoorfar, J. (2014) Global Safety of Fresh Produce. A Handbook of Best Practice, Innovative Commercial Solutions and Case Studies. Sawston, UK: Woodhead Publishing Limited. ISBN: 9781782420187 
Çoksever, E. (2009). Effect of Bitter Orange Albedo Addition at Different Concentrations on Quality of Naturally Fermented Turkish Style Sausages. M.D Thesis, Department of Food Engineering, Selcuk University.

Deo, P., Li, Y., Chatterjee, T., Stempek, R. (2019). Blends of Okara and a Fiber - Containing Pectin Product. The United States Patent Application Publication. Pub. No.: US 2019 / 0021383 A1.

Dudnyk, I., Janeček, E.R., Vaucher-Joset, J., Stellacci, F. (2018). Edible sensors for meat and seafood freshness. Sensors and Actuators B: Chemical, 259, 1108-1112.

https://doi.org/10.1016/j.snb.2017.12.057

Fajardo, S., García-Galvan, R.,F., Barranco, V., Galvan, J.C., Batlle, S.F. (2016). Role of Pectin in Food Processing and Food Packaging. Intech, I (tourism), 13.

https://doi.org/10.5772/57353

Falguera, V., Quintero, J.P., Jiménez, A., Muñoz, J. A., Ibarz, A. (2011). Edible films and coatings: structures, active functions and trends in their use. Trends in Food Science \& Technology, 22(6), 292-303.

https://doi.org/10.1016/j.tifs.2011.02.004

Fathi, B., Maghsoudlou, Y., Ghorbani, M., Khomeiri, M. (2012). Effect of $\mathrm{pH}$, temperature and time of acidic extraction on the yield and characterization of pectin obtained from pumpkin waste. Journal of Food Research, 22(4), 465-475.

Funami, T., Zhang, G.Y., Hiroe, M., Noda, S., Nakauma, M., Asai, I. (2007). Effects of the proteinaceous moiety on the emulsifying properties of sugar beet pectin. Food Hydrocolloids. 21(8), 1319-1329.

https://doi.org/10.1016/j.foodhyd.2006.10.009

Gavahian, M., Munekata, P.E.S., Eş, I., Lorenzo, J.M., Mousavi Khaneghah, A., Barba, F.J. (2019). Emerging techniques in bioethanol production: From distillation to waste valorization. Green Chemistry, 21(6), 1171-1185.

https://doi.org/10.1039/c8gc02698j

Gawkowska, D., Cybulska, J., Zdunek, A. (2018). Structure-related gelling of pectins and linking with other natural compounds: A review. Polymers, 10(7), 762.

https://doi.org/10.3390/polym10070762
Han, M., Bertram, H. C. (2017). Designing healthier comminuted meat products: Effect of dietary fibers on water distribution and texture of a fat-reduced meat model system. Meat Science, 133, 159-165.

https://doi.org/10.1016/j.meatsci.2017.07.001

Jafarzadeh, Y.R. (2015). Thermal Properties Of Different Fat Replacers Used In Frankfurter Production And Their Effects On Product Quality. M.D Thesis, Department Of Food Engineering, Hacettepe University.

Kachare, D. S., Ghadge, P.K., Sachin S.M. (2020). Role of Citrus Pectin in Biological Activity:A Rewiev, Journal of Pharmacovigilance and Quality Assurance. 2(1), 1-10.

Kang, H.J., Jo, C., Kwon, J.H., Kim, J.H., Chung, H.J., Byun, M.W. (2007). Effect of a pectin-based edible coating containing green tea powder on the quality of irradiated pork patty. Food Control, 18(5), 430-435.

https://doi.org/10.1016/j.foodcont.2005.11.010

Kim, H.-W., Miller, D.K., Lee, Y.J., Kim, Y.H.B. (2016). Effects of soy hull pectin and insoluble fiber on physicochemical and oxidative characteristics of fresh and frozen/thawed beef patties. Meat Science, 117, 63-67.

https://doi.org/10.1016/j.meatsci.2016.02.035

Ko, K., Lee, E., Baek, H., Son, M., Jeon, J., Jung, Y., Lim, E. (2014). "Processed Meat Product Without Added Phosphate, And Method Of Producing Same", United States Patent Application Publication. Pub. No.: US 2014/0134319 A1.

Korkmaz, F. (2018). Edible Films-Coatings and The Use in Aquaculture. Atatürk University Journal of the Agricultural Faculty, 49(1), 79-86.

https://doi.org/10.17097/ataunizfd.333596

Levigne, S., Ralet, M.-C., Thibault, J.-F. (2002). Characterization of pectin extracted from fresh sugar beet under different conditions using an experimental design. Carbohydrate Polymers, 49(2), 145-153.

https://doi.org/10.1016/S0144-8617(01)00314-9

Liu, L., Kerry, J.F., Kerry, J.P. (2007). Application and assessment of extruded edible casings manufactured from pectin and gelatin/sodium alginate blends for use with breakfast pork sausage. Meat Science, 75(2), 196-202.

https://doi.org/10.1016/j.meatsci.2006.07.008 
Maftoonazad, N., Ramaswamy, H.S., Marcotte, M. (2007). Evaluation of Factors Affecting Barrier, Mechanical and Optical Properties of Pectin-Based Films Using Response Surface Methodology. Journal of Food Process Engineering, 30, 539-563.

https://doi.org/10.1111/j.1745-530.2007.00123.x

Masuelli, M. (2019). Pectins: Extraction, Purification, Characterization, and Applications. Retrieved from https://www.intechopen.com (accessed 22.01.2020).

https://doi.org/10.5772/intechopen.78880

Méndez-Zamora, G., García-Macías, J.A., SantellanoEstrada, E., Chávez-Martínez, A., Durán-Meléndez, L. A., Silva-Vázquez, R., Quintero-Ramos, A. (2015). Fat reduction in the formulation of frankfurter sausages using inulin and pectin. Food Science and Technology (Campinas), 35(1), 25-31.

https://doi.org/10.1590/1678-457X.6417

Mudgil, D. (2017). The interaction between insoluble and soluble fiber. In Dietary fiber for the prevention of cardiovascular disease (pp. 35-59). Academic Press. ISBN: 9780128051306

https://doi.org/10.1016/B978-0-12-805130-6.00003-3

Naqash, F., Masoodi, F.A., Rather, S.A., Wani, S.M., Gani, A. (2017). Emerging concepts in the nutraceutical and functional properties of pectin-A Review. Carbohydrate polymers, 168, 227-239.

https://doi.org/10.1016/j.carbpol.2017.03.058

Narasimman, P., Sethuraman, P. (2016). An overwiev on the fundamentals of pectin. International Journal of $\mathrm{Ad}$ vanced Research, 4(12), 1855-1860.

https://doi.org/10.21474/IJAR01/2593

Ogutu, F.O., Mu, T.H. (2017). Ultrasonic degradation of sweet potato pectin and its antioxidant activity Ultrasonic Sonochemistry, 38, 726-734.

https://doi.org/10.1016/j.ultsonch.2016.08.014

Öztürk, B., Urgu, M., Serdaroğlu, M. (2016). Egg white powder-stabilized multiple (Water-in-olive oil-in-water) emulsions as beef fat replacers in model system meat emulsions. Journal of the Science of Food and Agriculture, 97(7), 2075-2083.

https://doi.org/10.1002/jsfa.8012
Panchami, P. S., Gunasekaran, S. (2017). Extraction and Characterization of Pectin from Fruit Waste. International Journal of Current Microbiology and Applied Sciences, 6(8), 943-948.

https://doi.org/10.20546/ijcmas.2017.608.116

Pappa, I., Bloukas, J., Arvanitoyannis, I. (2000). Optimization of salt, olive oil and pectin level for low-fat frankfurters produced by replacing pork backfat with olive oil. Meat Science, 56(1), 81-88.

https://doi.org/10.1016/s0309-1740(00)00024-3

Parkinson, D.R. (2014). Analytical Derivatization Techniques. Reference Module in Chemistry, Publisher: Molecular Sciences and Chemical Engineering. Edition: Vol 2 (Theory of Extraction Techniques), pp. 559-595.

https://doi.org/10.1016/B978-0-12-409547-2.11454-4

Ptichkina, N.M., Markina, O.A., Rumyantseva, G.N. (2008). Pectin extraction from pumpkin with the aid of microbial enzymes. Food Hydrocolloids, 22(1), 192-195. https://doi.org/10.1016/j.foodhyd.2007.04.002

Ramirez-suarez, J.C., Álvarez-armenta, A., García-sánchez, G. (2017). Effect of amidated low-methoxyl pectin on physicochemical characteristics of jumbo squid (Dosidicus gigas) mantle muscle gels. Food Tcehnology and Biotechnology 55(3), 398-404.

Ravishankar, S., Jaroni, D., Zhu, L., Olsen, C., Mchugh, T., Friedman, M. (2012). Inactivation of Listeria monocytogenes on ham and bologna using pectin-based apple, carrot, and hibiscus edible films containing carvacrol and cinnamaldehyde. Journal of Food Science, 7(77), 377-382.

https://doi.org/10.1111/j.1750-3841.2012.02751.x

Santiaguín-Padilla, A.J., Peña-Ramos, E.A., Pérez-Gallardo, A., Rascón-Chu, A., González-Ávila, M., GonzálezRíos, H., Islava-Lagarda, T. (2019). In vitro digestibility and quality of an emulsified meat product formulated with animal fat encapsulated with pectin. Journal of Food Science, 84(6), 1331-1339.

https://doi.org/10.1111/1750-3841.14626

Schmiele, M., Nucci Mascarenhas, M.C.C., da Silva Barretto, A.C., Rodrigues Pollonio, M.A. (2015). Dietary fiber as fat substitute in emulsified and cooked meat model system. LWT-Food Science and Technology, 61(1), 105-111. https://doi.org/10.1016/J.LWT.2014.11.037 
Sharma, P.C., Gupta, A., Kaushal, P. (2014). Optimization of method for extraction of pectin from apple pomace. Indian Journal of Natural Products and Resources, 5(2), 184-189.

Silva-Vazquez, R., Flores-Giron, E., Quintero-Ramos, A., Hume, M. E., Mendez-Zamora, G. (2018). Effect of inulin and pectin on physicochemical characteristics and emulsion stability of meat batters. CyTA-Journal of Food, 16(1), 306310.

https://doi.org/10.1080/19476337.2017.1403490

Tabak, D., Abadi, E., Serdaroglu, M. (2019). Evaluation of phosphate replacement with natural alternatives in chicken patties as a novel approach. IOP Conference Series: Earth and Environmental Science, 333(1), 012105.

https://doi.org/10.1088/1755-1315/333/1/012105

Thakur, B.R., Singh, R.K., Handa, A.K. (1997). Chemistry and Uses of Pectin - A Review. Critical Reviews in Food Science and Nutrition, 37, 47-73.

https://doi.org/10.1080/10408399709527767

Tufeanu, R., Tita, O. (2016). Possibilities to develop lowfat products: A review. Acta Universitatis Cibiniensis - Series E: Food Technology, 20(1), 3-19.

https://doi.org/10.1515/aucft-2016-0001

Tural, S., Türker Sarıcaoğlu, F., Turhan S. (2017). Yenilebilir film ve kaplamalar: üretimleri, uygulama yöntemleri, fonksiyonları ve kaslı gıdalarda kullanımları. Akademik Glda, 15(1), 84-94.

https://doi.org/10.24323/akademik-gida.306077

Uresti, R.M., López-Arias, N., González-Cabriales, J.J., Ramírez, J.A., Vázquez, M. (2003). Use of amidated low methoxy pectin to produce fish restructured products. Food Hydrocolloids, 17(2), 171-176.

https://doi.org/10.1016/S0268-005X(02)00049-8

Valdés, A., Burgos, N., Jiménez, A., Garrigós, M. (2015).
Natural pectin polysaccharides as edible coatings. Coatings 5 (4), 865-886

https://doi.org/10.3390/coatings5040865

Xiong, Y., Li, S., Warner, R.D., Fang, Z. (2020). Effect of oregano essential oil and resveratrol nano emulsion loaded pectin edible coating on the preservation of pork loin in modified atmosphere packaging. Food Control, 114, 107226. https://doi.org/10.1016/j.foodcont.2020.107226

Yadav, S., Malik, A., Pathera, A., Islam, R. U., Sharma, D. (2016). Development of dietary fibre enriched chicken sausages by incorporating corn bran, dried apple pomace and dried tomato pomace. Nutrition and Food Science, 46(1), 1629.

https://doi.org/10.1108/NFS-05-2015-0049

Yancheva, N., Markova, D., Murdzheva, D., Vasileva, I., Slavov, A. (2016). Foaming and emulsifying properties of pectin isolated from different plant materials. Acta Scientifica Naturalis, 3(1), 7-12.

https://doi.org/10.1515/asn-2016-0001

Yapo, B.M., Robert, C., Etienne, I., Wathelet, B., Paquot, M. (2007). Effect of extraction conditions on the yield, purity and surface properties of sugar beet pulp pectin extracts. Food Chemistry, 100(4), 1356-1364.

https://doi.org/10.1016/j.foodchem.2005.12.012

Younis, K., Ahmad, S. (2015). Waste utilization of apple pomace as a source of functional ingredient in buffalo meat sausage functional ingredient in buffalo meat sausage. Cogent Food \& Agriculture, 4(1), 1-10.

https://doi.org/10.1080/23311932.2015.1119397

Zeeb, B., Schöck, V., Schmid, N., Majer, L., Herrmann, K., Hinrichs, J., Weiss, J. (2018). Impact of food structure on the compatibility of heated WPI-pectin-complexes in meat dispersions. Food and Function, 9(3), 1647-1657.

http://doi.org/10.1039/C7FO01577A 